\title{
RABANI ( Reaktor Baru Wudhu Masa Kini) : Sistem Daur Ulang Air Wudhu yang Syar'i Berbasis Neo
}

\author{
Ema Cahyaningrum ${ }^{1}$ \\ Rinaldi Yunita Suci Rahayu ${ }^{2}$ \\ Emi Cahyaningrum ${ }^{3}$ \\ Universitas Diponegoro \\ Email : 'emacahyaningrum99@gmail.com, ${ }^{2}$ yunitasuci55@gmmail.com, \\ 3emicahyaningrum_bio@yahoo.com
}

\begin{abstract}
Indonesia is the country with the largest adherents of Islam in the world. The number of adherents of Islam is around 212.5 million people or about $80 \%$ of the total population. With the number of mosques in Indonesia around 731,096 buildings in 2013. Every Muslim (adherent of Islam) before praying always cleanses certain body parts commonly called ablution so that it is estimated that the use of water for ablution in a day is around 1.8 million m3. The dry season that occurred in the last few months has caused many areas to experience a clean water crisis. The use of water must be carried out optimally. Islam teaches how to be frugal and fair as taught in the apostles' Sunnah. Therefore, there is a need for a system designed to recycle used ablution so that it can be reused into ablution water. RABANI uses the NEO method (membrane based zeolite, electrocoagulation and ozonation) nanofiltration. The combination of several methods of water purification will increase the effectiveness of water purification so that better quality water is produced. This system produces output products in the form of clean water that is suitable for reuse for the purification process.
\end{abstract}

\section{Keywords: Water ablution, ozonizasi, referring}

\begin{abstract}
Abstrak
Indonesia merupakan negara dengan penganut agama Islam terbesar di dunia. Jumlah penganut agama Islam tersebut sekitar 212,5 juta jiwa atau sekitar $80 \%$ dari total penduduknya. Dengan jumlah masjid di Indonesia sekitar 731.096 bangunan pada tahun 2013. Setiap muslim sebelum melaksanakan ibadah sholat selalu membasuh bagian tubuh-tubuh tertentu yang biasa disebut wudhu sehingga diperkirakan penggunaan air untuk wudhu dalam sehari sekitar 1,8 juta $\mathrm{m}^{3}$. Musim kemarau yang terjadi beberapa bulan terakhir membuat banyak daerah mengalami krisis air bersih. Pemanfaatan air harus secara optimal dilakukan. Islam mengajarkan bagaimana bersikap hemat dan adil sebagaimana yang diajarkan dalam sunah rasul. Oleh sebab itu, perlu adanya sistem yang dirancang untuk mendaur ulang bekas air wudhu agar dapat digunakan kembali menjadi air wudhu. RABANI menggunakan metode NEO (Nanofiltrasi membran berbasis zeolit, Elektrokoagulasi, dan Ozonisasi). Adanya penggabungan beberapa metode penejernihan air ini, akan meningkatkan efektivitas penjernihan air sehingga dihasilkan air dengan mutu yang lebih baik. Sistem ini menghasilkan produk keluaran berupa air bersih yang layak dipakai kembali untuk proses bersuci. Meskipun dikatakan daur ulang limbah air wudhu atau yang biasa disebut musta'mal ini, ditinjau secara syari berdasarkan HR. Al-Bukhari no. 516 dapat dikategorikan sebagai air bersih yang mensucikan untuk digunakan kembali dalam proses berwudhu sehingga tujuan konsep ini selain dapat mengamalkan sunah rasul dalam melakukan penghematan air dan
\end{abstract}


terselenggaranya amalan wajib rukun Islam untuk shalat dalam keadaan bersuci sehingga dapat sebagai solusi inovatif penyelesaian krisis air saat ini.

\section{Kata kunci : Air wudhu, ozonizasi, syar'i}

\section{Pendahuluan}

Indonesia merupakan negara dengan jumlah penduduk terbesar ke empat di dunia dengan total penduduk sekitar 250 juta jiwa. Mayoritas penduduk Indonesia beragama Islam sekitar 80\% atau 212,5 juta jiwa yang menjadikan Indonesia sebagai negara dengan jumlah pemeluk Islam terbesar di dunia. Padahal menurut geografis letak Indonesia berada di benua Asia bagian tenggara yang notabene jauh dari negara asal agama Islam.

Sholat merupakan salah satu ritual wajib yang dilakukan oleh seorang muslim. Sebelum melakukan sholat seorang muslim diwajibkan suci dari najis sebagaimana disebutkan pada ayat AlQuran.

"Hai orang-orang yang beriman, apabila kamu hendak mengerjakan salat maka basuhlah mukamu, kedua tanganmu sampai siku dan sapulah kepalamu serta basuhlah kedua kakimu sampai mata kaki." (Q.S. Al-Maidah : 6).

Wudhu menurut bahasa artinya adalah bersih dan indah sedangkan menurut istilah (syariah Islam) artinya menggunakan air pada anggota badan tertentu dengan cara tertentu yang dimulai dari niat guna menghilangkan hadast kecil. Perspektif Islam mendefinisikan air merupakan media mensucikan diri. Ilmu mensucikan diri (disebut juga thaharah) dimana air berfungsi untuk membersihkan diri dari najis atau kotoran yang melekat pada tubuh. Meski dikatakan air suci, tidak semua kategori yang termasuk dapat secara sah digunakan untuk mensucikan.

Berdasarkan perhitungan sederhana dalam sehari muslim wajib melakukan sholat sebanyak lima kali. Dalam satu kali wudhu membutuhkan sekitar 5 liter atau 25 liter dalam sehari. Kemudian jika minimal jumlah orang yang pergi ke masjid adalah 50 orang maka 1250 liter setiap harinya terbuang. Jika jumlah ini diakumulasikan dalam skala nasional maka terdapat 1000 juta liter. Jumlah ini setara dengan kebutuhan air minum untuk seluruh peduduk Jawa, Kalimantan dan Sumatra. Sampai saat ini pemanfaatan air bekas wudhu hanya sebatas untuk menyiram tumbuh-tumbuhan, mencuci mobil, dan lain sebagainya. Namun, belum ada teknologi yang digunakan untuk merecycle air bekas wudhu menjadi sebagai air wudhu kembali yang syar'i dan memenuhi standar air bersih.

Menurut data Bappenas (2015) pada tahun 2025, seluas 78,4 persen wilayah di pulau Jawa akan mengalami defisit air selama satu hingga 12 bulan. Prediksi tersebut juga didukung oleh hasil studi para ahli melalui Forum Air Dunia yang memperkirakan bahwa Indonesia termasuk salah satu negara yang terancam akan mengalami krisis air pada 2025 mendatang. Hal ini disebabkan karena masyarakat lemah dalam hal pengelolaan air sehingga laju kebutuhan sangat tinggi dibandingkan tingkat ketersediaan. Selain itu musim kemarau yang terjadi terhitung pada bulan Februari 2019 ini menyebabkan beberapa daerah mengalami krisis air bersih. Krisis air dan kebutuhan air untuk berwudhu menjadikan dua masalah ini menjadi satu kesatuan sehingga diperlukan inovasi berupa sistem daur ulang limbah air wudhu menjadi dapat digunakan untuk air wudhu kembali.

Sunnah Rasulullah SAW mengajarkan tentang keutamaan menghemat air sebagaimana diriwayatkan dalam hadist yang berbunyi :Dari Abdullah bin Zaid radhiyallahu anhu, sesungguhnya 
Nabi Shallallaahu „Alaihi wa Sallam diberi air dua pertiga mud lalu beliau mulai menggosok dua tangannya dengan air itu." (HR Ahmad dan dinyatakan shahih oleh Ibnu Khuzaimah). Hal ini mengindikasikan keutamaan dalam berhemat air sebagaimana diamalkan oleh Rasulullah SAW dalam memanfaatkan dua pertiga mud segenggam penuh air bila kedua telapak tangan dipenuhi air (Abu, 2010).

Berdasarkan berbagai polemik permasalahan pemenuhan kebutuhan akan air serta anjuran yang ditunjukan oleh Al Quran dan Alhadis, penulis memiliki inovasi berupa Rabani ( Reaktor Baru Wudhu Masa Kini) : sistem daur ulang air wudhu yang syar'i metode NEO (Nanofiltrasi membran berbasis zeolit, Elektrokoagulasi, dan Ozonisasi). Nanofiltrasi membran zeolit merupakan proses filtrasi menggunakan membrane berpori berbahan dasar zeolite untuk memisahkan partikel tersuspensi, softening dan penghilangan produk samping desinfektan seperti zat organik alam dan sintentik. Membran berbasis zeolit dapat dimanfaatkan untuk minimisasi limbah dan recovery pelarut (Chau et al., 2000), pemisahan gas dari hidrokarbon, dehidrasi pelarut, remediasi polutan dan untuk produksi air bersih (Cui et al., 2008).

Pada gagasan ini, proses nanofiltrasi membran zeolit dikombinasikan dengan metode elektrokoagulasi. Elektrokoagulasi adalah proses destabilasi suspensi, emulsi dan larutan dengan cara mengalirkan arus listrik melalui air yang menyebabkan terjadinya reaksi oksidasi dan reduksi pada elektroda yang menyebabkan terbentuknya gumpalan yang mudah untuk dipisahkan. Melalui metode elektrokoagulasi, mampu menyisihkan berbagai jenis polutan dalam air yaitu partikel tersuspensi, logam-logam berat, zat pewarna dapat didegradasi (Ardhani A. F dan Dwi A, 2007).

Sementara itu, metode ozonisasi berperan dalam optimalisasi penjernihan air sungai. Ozon merupakan sebuah molekul gas yang terdiri dari tiga buah atom oksigen yang dapat berdekomposisi mejadi oksigen dalam waktu singkat, dan efektif dalam pendispersian untuk aktivitas anti mikroba. Dalam hal desinfeksi/ penjernihan air, fungsi teknologi ozon sangat efektif. Ozon digunakan sebagai desinfektan karena daya bunuhnya 3250 kali lebih cepat dibandingkan desinfektan seperti klorin (Isyuniarto, 2007). Adanya penggabungan beberapa metode penejernihan air ini, akan meningkatkan efektivitas penjernihan air sehingga dihasilkan air dengan mutu yang lebih baik.

\section{Metode Penelitian}

Sebelum diaplikasikan, terlebih dahulu dilakukan penelitian di Laboratorium Kimia Organik, Fakultas Sains dan Matematika serta Laboratorium Terpadu, Universitas Diponegoro, Semarang pada bulan Maret 2019. Penelitian dilakukan dengan kajian pustaka berdasarkan Al Qur'an dan Hadist serta Sains dan Teknologi. Sampel pada penelitian ini adalah air wudhu dalam tiga variasi waktu. Pada penelitian ini digunakan membran keramik zeolite, generator ozon, $\mathrm{pH}$ meter, penyaring kain, anoda galvalume, dan lain-lain. Gagasan ini dilakukan melalui tahapan langkah-langkah penjernihan air wudhu secara detail yang dapat dilihat pada gambar berikut: 


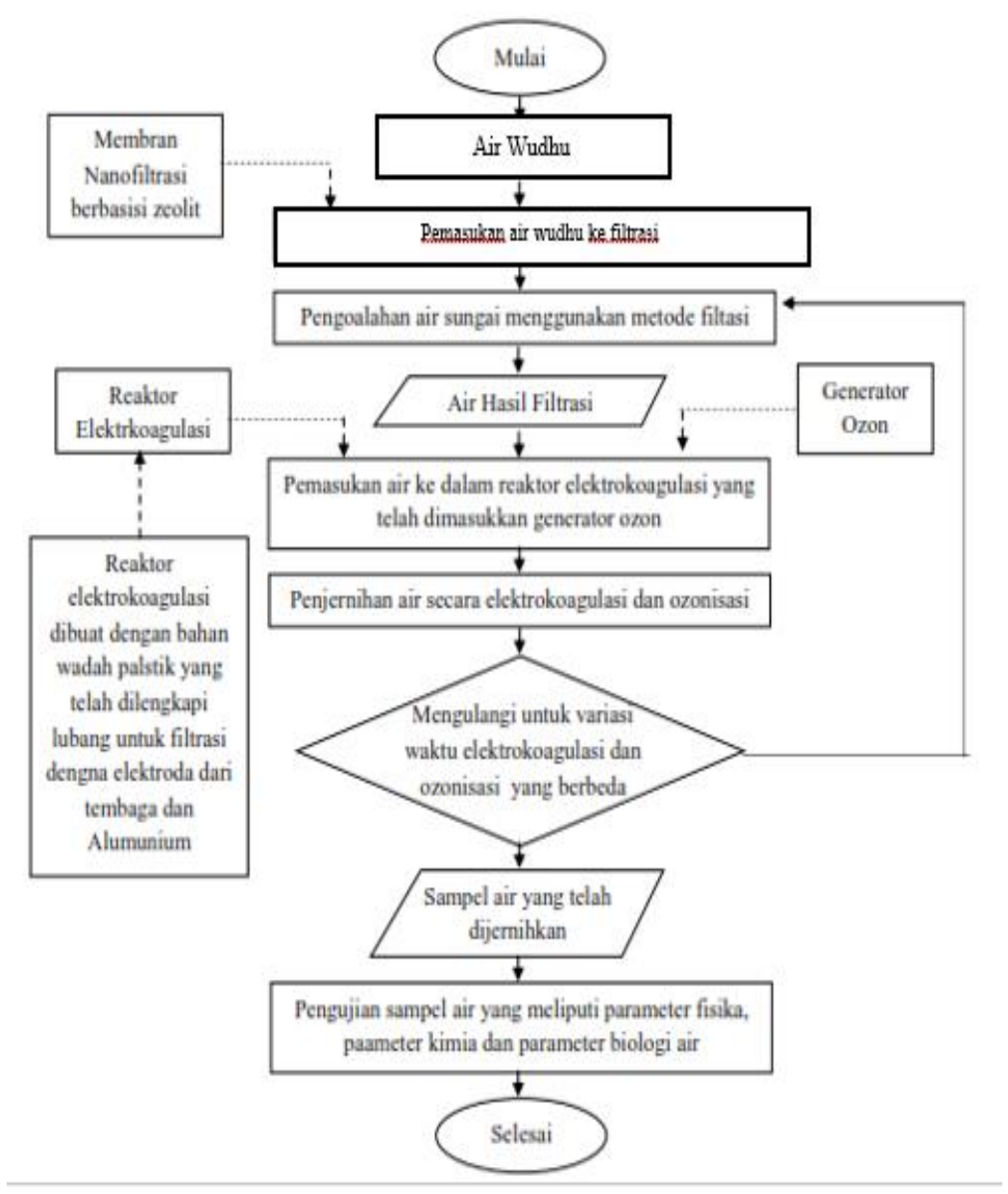

Gambar 1. Rancangan Diagram Alur Penjernihan Air

\section{Hasil dan Pembahasan}

Pada gagasan ini dilakukan penjernihan air wudhu dengan metode NEO (nanofiltrasi membran keramik zeolit, elektrokoagulasi, dan ozonisasi). Berikut adalah hasil penjernihan menggunakan metode elektrokoagulasi dan ozonisasi.

Tabel 1. Hasil Penjernihan Menggunakan Metode Elektrokoagulasi dan Ozonasi

\begin{tabular}{cccccccc}
\hline $\begin{array}{c}\mathrm{N} \\
\mathrm{O}\end{array}$ & $\begin{array}{c}\text { Parameter } \\
\text { yang perlu } \\
\text { diperiksa }\end{array}$ & $\begin{array}{c}\text { Satua } \\
\mathrm{n}\end{array}$ & $\begin{array}{c}\text { Kadar yang } \\
\text { Diperbolehka } \\
\mathrm{n}\end{array}$ & Kontrol & 30 menit & 60 menit & 90 menit \\
\hline 1 & Warna & - & $\begin{array}{c}\text { Tidak } \\
\text { berwarna }\end{array}$ & $\begin{array}{c}\text { Tidak } \\
\text { Berwarn } \\
\mathrm{a}\end{array}$ & $\begin{array}{c}\text { Tidak } \\
\text { Berwarna }\end{array}$ & $\begin{array}{c}\text { Tidak } \\
\text { Berwarna }\end{array}$ & $\begin{array}{c}\text { Tidak } \\
\text { Berwarna }\end{array}$ \\
\hline 2 & Bau & - & Tidak berbau & Berbau & $\begin{array}{c}\text { Tidak } \\
\text { Berbau }\end{array}$ & $\begin{array}{c}\text { Tidak } \\
\text { berbau }\end{array}$ & $\begin{array}{c}\text { Tidak } \\
\text { berbau }\end{array}$ \\
\hline 3 & Rasa & - & Tidak berasa & $\begin{array}{c}\text { Tidak } \\
\text { berasa }\end{array}$ & $\begin{array}{c}\text { Tidak } \\
\text { Berasa }\end{array}$ & $\begin{array}{c}\text { Tidak } \\
\text { Berasa }\end{array}$ & $\begin{array}{c}\text { Tidak } \\
\text { Berasa }\end{array}$ \\
\hline 4 & $\begin{array}{c}\text { Turbidity } \\
\text { (kekeruhan })\end{array}$ & NTU & 5 & 14,72 & 6,57 & 0,86 & 1,16 \\
\hline
\end{tabular}




\begin{tabular}{cccccccc}
\hline 5 & $\begin{array}{c}\text { Total zat padat } \\
\text { terlarut }\end{array}$ & $\mathrm{Mg} / 1$ & 500 & 184 & 171 & 150 & 139 \\
\hline 6 & $\begin{array}{c}\text { Derajat } \\
\text { Keasaman } \\
(\mathrm{pH})\end{array}$ & $\mathrm{Mg} / 1$ & $6,5-8,5$ & 7,26 & 8,32 & 8,21 & 8,51 \\
\hline 7 & $\begin{array}{c}\text { Kesadahan } \\
(\text { CaCO3) }\end{array}$ & $\mathrm{Mg} / 1$ & 500 & 176,00 & 122,00 & 96,00 & 88,00 \\
\hline 8 & Calsium & $\mathrm{Mg} / 1$ & - & 43,30 & 36,09 & 29,67 & 27,26 \\
\hline 9 & Magnesium & $\mathrm{Mg} / 1$ & - & 32,25 & 20,88 & 16,12 & 14,76 \\
\hline 10 & Ferum & $\mathrm{Mg} / 1$ & 0,3 & 0,36 & 0,31 & 0,11 & 0,14 \\
\hline 11 & Tembaga & $\mathrm{Mg} / 1$ & 2 & 0,09 & 0,07 & 0,04 & 0,06 \\
\hline 12 & Amonia & $\mathrm{Mg} / 1$ & 1,5 & 0,39 & 0,09 & 0,08 & 0,06 \\
\hline
\end{tabular}

Sumber : Penulis

Berdasarkan hasil percobaan pada tabel 1 terbukti bahwa metode elektrokoagulasi dan ozonisasi dapat memperbaiki karakteristik fisika dan kimia air wudhu. Adapun perbandingan air sebelum dan sesudah diolah dapat dilihat pada gambar 2 berikut:

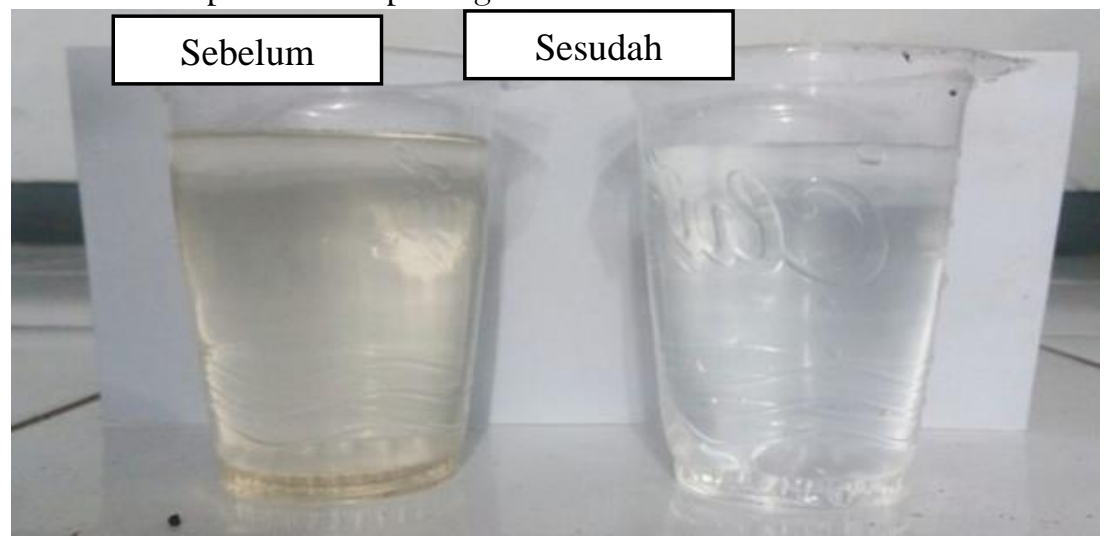

Gambar 2. Perbedaan Air Sebelum dan Setelah Diolah.

Penggunaan membran keramik zeolit akan berpengaruh terhadap rejeksi kandungan bahan-bahan kimia yang sulit untuk didegradasi seperti fosfat.. Semakin tebal membran nilai rejeksi juga akan semakin meningkat. Ukuran pori dan tebal membran akan secara otomatis mempengaruhi tingkat rejeksi dari membran tersebut (Notodarmojo dan Deniva, 2004). Tidak hanya menyebabkan terjadinya rejeksi fosfat, membran keramik zeolit dengan komposisi material berupa tanah liat, zeolit dan serbuk besi dengan perbandingan tertentu mampu menurunkan parammeter pencemar pada air limbah laundry yang meliputi TDS, EC, COD, $\mathrm{BOD}_{5}$ dan $\mathrm{LAS}$.

Setelah melewati pengolahan dengan metode filtrasi, air wudhu akan masuk ke dalam pengolahan dengan metode elektrokoagulasi. Metode elektrokoagulasi mampu mengendapkan flok-flok yang ada pada air sehingga menyebabkan perubahan kadar kekeruhan pada air yang menyebabkan air menjadi lebih jernih. Semakin lama waktu tinggal limbah dalam reaktor memberikan kesempatan kontaminan dalam limbah mengendap dan proses elektrokoagulasi yang lebih lama sehingga kadar TDS pada air juga semakin kecil (Karamah dan Bismo, 2006).

Selain itu, selama dalam proses elektrokoagulasi akan terjadi penurunan kadar logam dalam air seperti Kalsium (Ca), Magnesium $(\mathrm{Mg})$, besi $(\mathrm{Fe})$, dan tembaga $(\mathrm{Cu})$. Hal ini disebabkan karena transformasi logam dari fasa cair ke fasa padat. Logam membentuk senyawa logam 
hidroksida dan oksida logam kompleks yang tidak larut dalam air. Senyawa ini selanjutnya berinteraksi melalui gaya adsorbsi ke struktur rongga koagulan yang dihasilkan dari anoda galvalum. Interaksi antar senyawa tak larut akan menghasilkan flok (Mukimin, 2006). Selain itu juga disebabkan karena proses elektrokoagulasi mengambil lebih dari 99\% kation beberapa logam (Renk, 1989; Duffey, 1983; Frao, 1974 dalam Mukimin, 2006). Penurunan kadar logam, terutama untuk logam Calsium (Ca) memiliki pengaruh yang besar terhadap kesadahan air. Hal ini disebabkan karena terjadi penurunan kadar logam Ca dalam air akibat elektrokoagulasi yang menyebabkan konsentrasi $\mathrm{CaCO}_{3}$ berkurang. Selain itu, penurunan kesadahan air juga disebabkan oleh alkalinitas dalam air. Alkalinitas menunjukkan kandungan karbonat $\left(\mathrm{CO}_{3}{ }^{2}\right)$ dan bikarbonat $\left(\mathrm{HCO}_{3}{ }^{-}\right)$yang akan berkurang seiring dengan adanya kenaikan $\mathrm{pH}$ (Sari, dkk, 2013).

Sementara itu, tahap terakhir adalah proses ozonisasi. Air hasil elektrokoagulasi yang telah disaring oleh penyaring kain merupakan air yang cukup jernih yang selanjutnya diozonisasi untuk menghilangkan bakteri-bakteri patogen dan senyawa-senyawa organik. Ozon dapat berdekomposisi menjadi oksigen dalam waktu singkat, dan efektif dalam pendispersian untuk aktivitas anti mikroba. Reaksi tidak langsung ozon akan menghasilkan radikal hidroksil yang dapat bereaksi dengan mikropolutan organik maupun anorganik (Azamia, 2012). Molekul Ozon bersifat tidak stabil dan akan selalu berusaha mencari 'sasaran' untuk dapat melepaskan satu atom oksigen dengan cara oksidasi, sehingga dapat berubah menjadi molekul oksigen yang stabil $\left(\mathrm{O}_{2}\right)$ karena sifat oksidatornya yang sangat kuat, maka ozon sangat unggul untuk disinfeksi (membunuh kuman), detoksifikasi (menetralkan racun) dan deodorisasi (menghilangkan bau tidak enak) dalam air.

Selain itu, pengaruh dari penggunaan generator ozon terjadi pada kenaikan $\mathrm{pH}$. Kadar amonia yang menyebabkan bau akan mengalami penurunan. Penurunan ini dikarenakan hidroksil $\mathrm{OH}^{\prime}$ yang dihasilkan oleh ozon akan beperan dalam mengoksidasi amonia dimana proses oksidasi ini akan bekerja optimum pada pada $\mathrm{pH}$ basa (Fahmiati, 2012). Mengingat bahwa ozon sendiri dapat meningkatkan $\mathrm{pH}$ karena produksi dari ion $\mathrm{OH}^{-}$nya, tentunya penurunan kadar bau akibat ammonia oleh reaktor ozon sangat efektif.

Selanjutnya, kontribusi $\mathrm{pH}$ juga terjadi pada penurunan jumlah logam terlarut dimana hal ini dipengaruhi oleh ketersediaan ion hidroksi. Penurunan kandungan logam hasil pengolahan dipengaruhi oleh meningkatnya $\mathrm{pH}$. Hal ini disebabkan oleh efek ion $\mathrm{OH}$. Semakin tinggi jumlah ion $\mathrm{OH}^{-}$maka gelembung gas oksigen dan hidrogen yang dihasilkan dari reaksi ozon dengan air juga akan meningkat sehingga akan meningkatkan kinerja dari flotasi (Mukimin, 2006).

Kajian sistem Rabani berdasarkan syariat Islam yaitu Allah SWT. mengajarkan kepada manusia untuk menjaga kebersihan serta kesucian terutama ketika hendak melakukan sholat dengan cara berwudhu.

"Hai orang-orang yang beriman, apabila kamu hendak mengerjakan salat maka basuhlah mukamu, kedua tanganmu sampai siku dan sapulah kepalamu serta basuhlah kedua kakimu sampai mata kaki." (Q.S. Al-Maidah : 6).

Penggunaan limbah air wudhu (air musta'mal) sebagai air wudhu kembali diperbolehkan dalam Islam selama ia tidak keluar dari nama air muthlaq atau tidak menjadi najis disebabkan tercampur dengan sesuatu yang najis sehingga merubah bau, rasa atau warnanya.. Inilah pendapat yang dianut oleh 'Ali bin Abi Tholib, Ibnu 'Umar, Abu Umamah, sekelompok ulama salaf, pendapat yang masyhur dari Malikiyah, merupakan salah satu pendapat dari Imam Asy Syafi'i dan 
Imam Ahmad, pendapat Ibnu Hazm, Ibnul Mundzir dan Syaikhul Islam Ibnu Taimiyah Lihat Shahih Fiqh Sunnah, 1/104.. Hadist Riwayat Bukhori no. 187 menjelaskan:

"Rasulullah shallallahu 'alaihi wa sallam pernah keluar bersama kami di al Hajiroh, lalu beliau didatangkan air wudhu untuk berwudhu. Kemudian para sahabat mengambil bekas air wudhu beliau. Mereka pun menggunakannya untuk mengusap"

Dalam kajian diatas air musta'mal adalah air bekas yang masih suci atau tidak terkena benda suci dalam jumlah banyak. Secara komposisi kimia dapat dijelaskan bahwa syarat air dikatakan bersih suci adalah ; jernih (tidak berwarna), tidak berbau, $\mathrm{pH}$ berkisar takaran 7 dengan kandungan air bersih (paling sedikit mengandung $5 \mathrm{ppm} /$ part per million DO Dissolved Oxygen, maksimum kandungan zat padat terlarut 1000 ppm, mengandung BOD Biological Oxygen Demand kurang dari $1 \mathrm{ppm}$ ) (Yoga, 2011) sehingga penggunaan air daur ulang dari sistem Rabani telah masuk dalam kategori air yang musta'mal, sehingga dapat digunakan untuk bersuci.

Dengan demikian, melalui berbagai data analisa yang diperoleh terkait dengan solusi berupa Rabani ( Reaktor Baru Wudhu Masa Kini) : Sistem Daur Ulang Air Wudhu yang Syar'i Berbasis NEO diharapkan dari bekas air wudhu akan dihasilkan air bersih dengan kualitas yang lebih baik. Melalui teknik ini, satu langkah pemerintah Indonesia dalam mengatasi krisis air bersih dapat diwujudkan melalui pengimplementasian dari gagasan guna mewujudkan Indonesia dalam menghadapi industri 4.0.

\section{Kesimpulan}

Dari hasil penelitian dan pembahasan pengolahan air bekas wudhu menurut Al qur'an dan Hadist dapat disimpulkan bahwa aplikasi sistem Rabani merupakan salah satu upaya meminimalisir krisis air di Indonesia tahun 2025. Rabani menjadi media yang tepat dalam memanfaatkan air musta'mal untuk berwudhu dan NEO memiliki beberapa keunggulan yaitu metode peningkatan daya selektifitas. Saran dalam penelitian ini yaitu perlu dilakukan penelitian lebih lanjut dan adanya dukungan dari pemerintah sehingga Rabani dapat diaplikasikan ke seluruh Indonesia.

\section{DAFTAR PUSTAKA}

Azamia, Mia. 2012. Pengolahan Limbah Cair Laboratorium Kimia dalam Penurunan Kadar Organik serta Logam Berat Fe, Mn, Cr dengan Metode Koagulasi dan Adsorpsi. Skripsi. Depok : Universitas Indonesia

Chau, J.L.H, C.Tellez, K.L. Yeung , K. Ho. 2000. The Role of Surface Chemistry in Zeolite Membrane Formation. Journal of Membrane Science. Vol 16: 257-275

Cui, J., Zhang, Z., Liu, H., Liu, S., Yeung, K.L. 2008. Preparation And Application Of Zeolite/Ceramic Microfiltration Membranes For Treatment Of Oil Contaminated Water. Journal of Membrane Science. Vol $25: 420-426$

Fahmiati, Sri. 2012. Pengaruh Suhu Umpan Pada Penyisihan Amonia dari Air Limbah Menggunakan Kombinasi Proses Membran dan Ozonisasi. Skripsi. Depok : Fakultas Teknik Universitas Indonesia 
Isyuniarto, Agus Purwadi. 2007. Pengaruh pH dan Oksidan Ozon Terhadap Jumlah Bakteri Coliforrm pada Limabh Rumah Sakit ( Studi Kasus Limabh RSUD Kota Yogyakarta). Prosiding PPIPDIPTN. Batan : Pusat Teknologi Akselerator dan Proses Bahan.

Karamah, E. F., dan Bismo, S.. 2006. Pengaruh Dosis Koagulan PAC Dan Surfaktan SLS Terhadap Kinerja Proses Pengolahan Limbah Cair Yang Mengandung Logam Besi(Fe), Tembaga (Cu), Dan Nikel (Ni) Dengan Flotasi Ozon. Departemen Teknik Kimia, Fakultas Teknik Universitas Indonesia. Kampus UI Depok.

Mukimin, Aris. 2006. Pengolahan Limbah Industri Berbasis Logam dengan Teknologi Elektrokoagulasi Flotasi. Tesis. Semarang : Universitas Diponegoro.

Sari, Nurita N., Sururi M.R., Pharmawati, K. 2013. Efek Perlakuan pH pada Ozonisasi. Jurnal Reka Lingkungan. Vol 1(1):4-14 